\title{
Public - private partnerships and contested cultural heritage tourism in national parks: a case study of the stakeholder views of the North Head Quarantine Station (Sydney, Australia)
}

\author{
S. Darcy* and S. Wearing
}

School of Leisure Sport and Tourism, University of Technology Sydney, Lindfield, NSW, Australia

This paper examines the public perceptions of stakeholders towards a proposed cultural heritage public-private partnership (PPP) within a national park in Sydney, Australia. Governments in Australia are initiating PPPs for the purposes of designing, planning, constructing and operating projects that would traditionally be regarded as 'public goods'. The North Head Quarantine Station (Sydney, Australia) was one of the first proposed PPPs in national parks that moved beyond the licensing of private sector operations within park boundaries. The Quarantine Station is used as a case study to offer insights into the PPP process because of its place in the cultural heritage of Australia, its prime a facie tourism position within Sydney Harbour and its prolonged history of development. The case study provides a mechanism for examining public opinion on cultural heritage tourism issues in national parks through understanding stakeholder perspectives presented in newspaper media accounts. The accounts are analysed on political and environmental considerations with implications drawn for future developments.

Keywords: protected areas; public-private partnerships; stakeholders; cultural heritage

\section{Introduction}

In liberal market economies individual and community needs and policy agendas are predominantly determined by the interplay of government regulation and market forces. A tension exists where these forces are seen as a dichotomy of government or market. Public-private partnerships (PPPs) bring these forces together in a process that tries to incorporate the public interest agenda with the economic use-value of the market (Ready \& Navrud, 2002). This paper examines a contemporary example of a cultural heritage PPP that is located in, and, under the governance of the New South Wales (NWS) National Parks and Wildlife Service (NPWS). A background to the issue will be provided through a discussion of PPPs in a changing public sector, the role of tourism in cultural heritage and stakeholder perspectives. Once this has been completed, the case study area and methodology will be outlined. Newspaper articles discussing the development are then analysed for the stakeholder perspectives. The analysis utilises Turner's (1981) anthropocentricecocentric continuum and Dear's (1992) not-in-my-backyard (NIMBY) syndrome. The

\footnotetext{
*Corresponding author. Email: simon.darcy@uts.edu.au
} 
analysis is designed to provide a framework to understand stakeholder positions on the proposed PPP of the Quarantine Station. The findings and discussion are then presented prior to the broader implications for cultural heritage tourism management.

PPPs in a changing public sector

The introduction of PPPs has come at a time when the public sector in Australia is undergoing a radical transformation. Neo-liberal approaches to the different spheres of government have been well documented generally, as well as with respect to tourism (Burns, 2004). A general reduction in the size of the public sector, along with a change in its form and function have raised questions as to which areas should be regarded as 'public goods' and which areas belong to the domain of the market. Due to a revision of the rationale for government involvement, changing economic and political imperatives have resulted in a 'squeeze' on public funds. Governments are facing an increasing level of scrutiny of their activities not only on grounds of effectiveness and efficiency but also questions as to the appropriateness of government involvement in programs (Dredge \& Jenkins, 2003).

PPPs have been advocated in Australia as a strategy for efficient use of government resources and as a way to avoid budget deficits. PPPs can be defined as:

... partnerships between the public sector and the private sector for the purposes of designing, planning, financing, constructing and/or operating projects which would be regarded traditionally as part of the public sector (Webb \& Pulle, 2002).

Governments, the private sector and the public have, to some degree, accepted PPPs as an instrument of government economic management. However, substantial shifts toward both private sector involvement and the privatising of state-owned goods and services require a comprehensive debate and the development of guidelines about the appropriateness of implementing PPPs in any given context. It has been suggested that Australian governments adopt frameworks that apply to specific services and industries, and prohibit privatisation of services in which private ownership would be contentious (King \& Pitchford, 1998, p. 313).

The neo-liberal commitment to small government and the lack of adequate resources for public sector management (Veal, 2002) is also fuelling a substantial push in some states for a greater role for the private sector in managing national parks (Christoff, 1998; Lockwood \& Dirk, 2001). As Prasser (1996) also notes, the impact of the decreasing resources has been compounded by increases in designation of national park areas and public demand (access, activities and facilities). The privatisation debate within national parks has involved the delivery of parks maintenance, accommodation, food transport and tour services, to a far more radical approach where the government's role would retreat to setting standards and monitoring outcomes of privately developed and operated enterprises. In particular, the need for private commercial accommodation in national parks has considerable support from the tourism industry (Charters, 1996; Eagles, McCool, \& Haynes, 2002; Gabriel, 1996), but proposals can often meet a determined community backlash (Lockwood \& Dirk, 2001; Page, 2006). The prevailing philosophy of such industry proponents is deeply anthropocentric, that is a human demand for tourism exists therefore it must be met. Yet, their arguments for privatisation of aspects of national park operations are couched in terms of 'protecting' the parks through better maintenance and management of the 'inevitable' demands.

A combination of factors has led to this situation. First, the momentum is directly related to the reduced funding of many national park agencies (Bella, 1987; Cree, 1985; 
Prasser, 1996). Tourism facilities can generate funds and many land agencies are actively encouraging further use. Second, from this an issue arises as to the increasing dependence of parks authorities on charges levied on tourists to meet budget shortfalls. There remains widespread concern in the environment movement that this creates an inexorable dynamic towards tourism centred management where national parks continually push towards greater tourism use to generate income (Figgis, 1999; United Nations Environment Programme, 2005). Table 1 presents some Australian examples of these two compounding pressures.

In this study, the changing role of private enterprise in national parks, together with the increasing prominence of multiple use models (McArthur, 2001), are used to provide a context for the case study. From the 1990s, there has been an increasing level of dispute over PPPs as governments have sought the involvement of the private sector in the maintenance, development and redevelopment of infrastructure. Stakeholder views of cultural heritage related developments for the purpose of protection and tourism, often involve heated contestation amongst stakeholders (Easterling, 2004). As the International Union for the Conservation of Nature (IUCN) recognise, the understanding of and collaborative management for stakeholder perspectives should be central to any management processes (Borrini-Feyerabend, 1996; United Nations Environment Programme, 2005). In the Australian context, issues surrounding the development or redevelopment of cultural heritage sites

Table 1. Examples of private use of national parks.

\begin{tabular}{|c|c|}
\hline Area & Development \\
\hline $\begin{array}{l}\text { Wilson’s Promontory National } \\
\text { Park (Victoria) }\end{array}$ & $\begin{array}{l}\text { Lodge for } 150 \text { people, a backpacker hostel and commercial lodges } \\
\text { along walking tracks. While the hotel was dropped after public } \\
\text { protest, the other developments are going ahead }\end{array}$ \\
\hline $\begin{array}{l}\text { Nobbies area of Phillip Island } \\
\text { (Victoria) }\end{array}$ & $\begin{array}{l}\$ 60 \text { million 'ecotourism' development. Tunnel with a train to a } \\
\text { viewing tower above a seal colony. A } \$ 13 \text { million first stage has } \\
\text { been approved }\end{array}$ \\
\hline $\begin{array}{l}\text { Queensland Environment } \\
\text { Minister }\end{array}$ & $\begin{array}{l}\text { Issued guidelines for commercial developments in national parks } \\
\text { as a means of generating revenue to pay for 'improved } \\
\text { management'. Proposals have been received for developments } \\
\text { on Fraser Island and inside Carnarvon National Park with } \\
\text { Wallaman Falls }\end{array}$ \\
\hline $\begin{array}{l}\text { Warrumbungle National Park } \\
\text { (NSW) }\end{array}$ & $\begin{array}{l}\text { Nine development sites were proposed to cater for overnight } \\
\text { camping and cabins despite a town, Coonabarabran, existing } \\
\text { nearby. The accommodation will be run by private enterprise }\end{array}$ \\
\hline $\begin{array}{l}\text { Kosciusko National Parks } \\
\text { (NSW) }\end{array}$ & $\begin{array}{l}1000 \text { bed expansion of existing ski resort. Part of the development } \\
\text { involves substantial commercial retail space and private } \\
\text { apartments. Proposals also exist for Blue Cow, Guthega and } \\
\text { Smiggins ski resorts }\end{array}$ \\
\hline Tasmanian Parks Service & $\begin{array}{l}\text { Promotion of a 'wilderness development' site at Pumphouse Point } \\
\text { in Lake St Clair National Park. }\end{array}$ \\
\hline Alpine National Park (Victoria) & $\begin{array}{l}285 \text { ha has been excised from the park for a downhill ski runs and } \\
\text { tourist development }\end{array}$ \\
\hline
\end{tabular}

Tourism management pressure

Great Barrier Reef Marine Park (Queensland)

Ottaway National Park (Victoria)

Two Peoples Bay (Western

Increase in the 'reef tax' from \$1to \$6 per head on commercial operators taking tourists to the Great Barrier Reef Marine Park

Great Ocean walk extension prime coastal locations with no consultation

Reserve status altered to allow for a tourism centre despite concerns over environmental integrity 
can be seen in the media coverage they attract. The degree of coverage will depend on the scale of the development and the relative significance of the site. For the majority of the public, the contestation generally plays out in the newspaper press and occasionally on local, regional and national television.

The role of tourism in cultural heritage

Timothy and Boyd (2006) articulated a need to better understand the supply side of cultural heritage tourism and to develop new management solutions. Many of Australia's most globally recognised tourism icons are located within protected areas. Protected areas in this paper refer to the many designations of natural areas placed under the protection of government. In Australia, there are many designations of natural areas under a plethora of state legislation (Inglis, Whitelaw, \& Pearlman, 2006). For the purposes of this paper the term 'national parks' will be used because of the governance context of the case study. World Heritage listed icons such as Uluru, Kakadu, the Great Barrier Reef and much of Sydney Harbour's foreshore are all under the protection of state national park legislation. These national parks are of great importance to the cultural heritage of Australians and are major drawcards of the Australian tourism industry. The Federal Government's Tourism White Paper suggested that cultural heritage tourism provided an opportunity to expand the breadth of unique experiences offered by the industry nationwide (Commonwealth Department of Industry Tourism and Resources, 2003).

Tourism has escalated the demand for these areas further with questions raised as to the sustainability of heavily used areas and areas that are environmentally fragile. As a result, site hardening becomes essential along with greater ranger patrolling. For most national park agencies this is believed to be a less than effective use of limited park resources, particularly when the return from tourists to date has been marginal. Solutions to this dilemma have seen the tourism industry lease designated areas within national parks where they accept responsibility for the economic, social and environmental management of the sites. In Australia, all alpine areas with designated slopes for skiing have been managed in this way for the last 30 years (Buckley, Pickering, \& Weaver, 2003). Most of these arrangements have been made through forms of site leasing where PPPs are being used to replace traditional types of national park management.

While much of the reform pressure to date has focussed on public sector activities with a demonstrably commercial potential, national parks have not been exempt from this pressure (Buckley, 2004b; Herath \& Kennedy, 2004; Sibly, 1998). Parks’ management are currently grappling with issues associated with the realignment of their organisations in a more demanding public sector environment (Commonwealth Grants Commission, 2006). The 170 economic benefit of encouraging tourism has only recently begun to be recognised within national parks organisations, and parks' management must deal with the issue of increasing the economic benefit of tourism while simultaneously maintaining traditional conservation objectives (Herath \& Kennedy, 2004). As a result, the management and protection of national parks is being challenged by increasing use, and public sector land managers have to focus on a conservation approach with limited accountability in terms of income returned (Buckley, 2004b). This is partly due to a lack of valid and reliable visitor information systems on which to base decisions (Darcy, Griffin, Craig, Crilley, \& Moore, 2007). Yet, any change in the strategic direction of protected area agencies also requires a redefinition of management approaches.

The other dynamic in undertaking PPPs is the change process that the individual sites must undergo to move from preservation or conservation orientations of protected areas, to 
a market/business orientation of a tourism enterprise. This change process must incorporate a broader understanding of stakeholder views. We suggest that there is a need for mechanisms to monitor public opinion to ensure that as a part of this process they are able to operate in the interests of the public they serve. Surprisingly, little work has been carried out on stakeholder views of cultural heritage development in Australia. Yet, the IUCN has advocated for such stakeholder understandings for over a decade (Borrini-Feyerabend, 1996).

As a part of the need to monitor public opinion, we need to look at the core issues for agencies like NPWS whose mission includes an ethic to care for and conserve nature, to demonstrate how people can obtain quality experiences and to ensure a greater appreciation of the consequences of human action on nature. PPPs in national parks offer an opportunity for cultural heritage tourism to be incorporated into this process to maintain and improve the built environment and to develop a quality of experience on which to base sustainable and profitable tourism ventures.

\section{Stakeholder perspectives}

This paper does not employ stakeholder theory in a theoretical sense but an understanding of stakeholder theory is required as a background to the Quarantine Station case study. Stakeholder theory, developed from the field of strategic management studies, acknowledges that the conflicting perspectives of stakeholders need to be managed as part of organisational objectives (Freeman, 1983). Yet there is no universal definition of 'stakeholder' in the strategic management or tourism literature. In the tourism context, stakeholder theory has been used synonymously in relation to government management of environmental development processes (Sautter \& Leisen, 1999). For this study, stakeholder will be defined as, 'any individual, interest group, pressure group or corporation affected by a public policy issue, government action or inaction' (adapted from Davis, Wanna, Warhurst, \& Weller, 1993; Hall, 1999; Mitchell, Agle, \& Wood, 1997).

While it may not always be possible to represent the claims of all stakeholders in this case study, the use of media sources provides an overview of those involved in the public contestation and the perspectives that are publicly represented. The main contribution of such an analysis is to be able to identify from the perspectives of the stakeholders, the issues they regard as significant to the proposed changes and incorporate these views into management strategies. As Sautter and Leisen (1999, p. 312) emphasise, collaboration among key players is a 'fundamental ingredient in sustainable development'. Stakeholder groups hold considerable power to influence the community and receive considerable media coverage. Jamal and Getz (1995) suggest the lack of coordination and collaboration in the tourism industry hinders coordination between stakeholders and we suggest that community involvement in planning and development is critical to the overall sustainability of tourism in a destination region. Historically there is a need for this understanding where citizen movements have had a major impact on the environmental landscape.

The case study area

The North Head Quarantine Station, Sydney, NSW resides within the North Head National Park, which is under the control of the NSW NPWS. The NPWS is part of the NSW Government's Department of Environment and Climate Change. The Quarantine Station is an Australian cultural heritage icon listed in the Australian heritage register. Apart from the built environment and its role in Australia's migration history, it has a significant area of remnant coastal heath containing a number of endangered species (bandicoots, 
stringy bark trees and fairy penguins) and items of indigenous heritage (Manidis Roberts Consultants, 2004; NSW National Parks and Wildlife Service, 2001).

The first use of North Head as a quarantine site was in August 1828 with the detaining of the convict ship Bussorah Merchant when a number of crew became infected with smallpox. After this, it was further developed to include accommodation blocks, hospital wards, a morgue, and an administration centre, which remained in operation until the early 1980s. During its time, 580 ships were detained at North Head and more than 13,000 people were quarantined. The Quarantine Station is considered a place of national, historical and social significance. Many immigrants to Australia spent their first few weeks there either recovering from illness or waiting to make sure they had not contracted an illness. Those who have stayed here are considered representative of the various stages of immigration to Australia (NSW National Parks and Wildlife Service, 2001). The site contains a number of important elements such as medical, immigration and maritime history (Manidis Roberts Consultants, 2004). The NPWS has operated guided tours and a historical resource centre for the education of visitors. The existing condition of the Quarantine Station has been formally assessed with the conclusion that:

The buildings and sites comprising the Quarantine Station range from good to poor condition. The Station fabric was 'run-down' prior to hand over in 1984, and there have been subsequent attempts to address maintenance requirements, but these have lacked sufficient resources to maintain the entire site (Peter Freeman Pty Ltd, 2000).

As Figure 1 illustrates, the location of the site would provide an impressive vista for any tourism operation. This together with the state of the Quarantine Station infrastructure brought it under scrutiny as a site where alternative management options may be viable

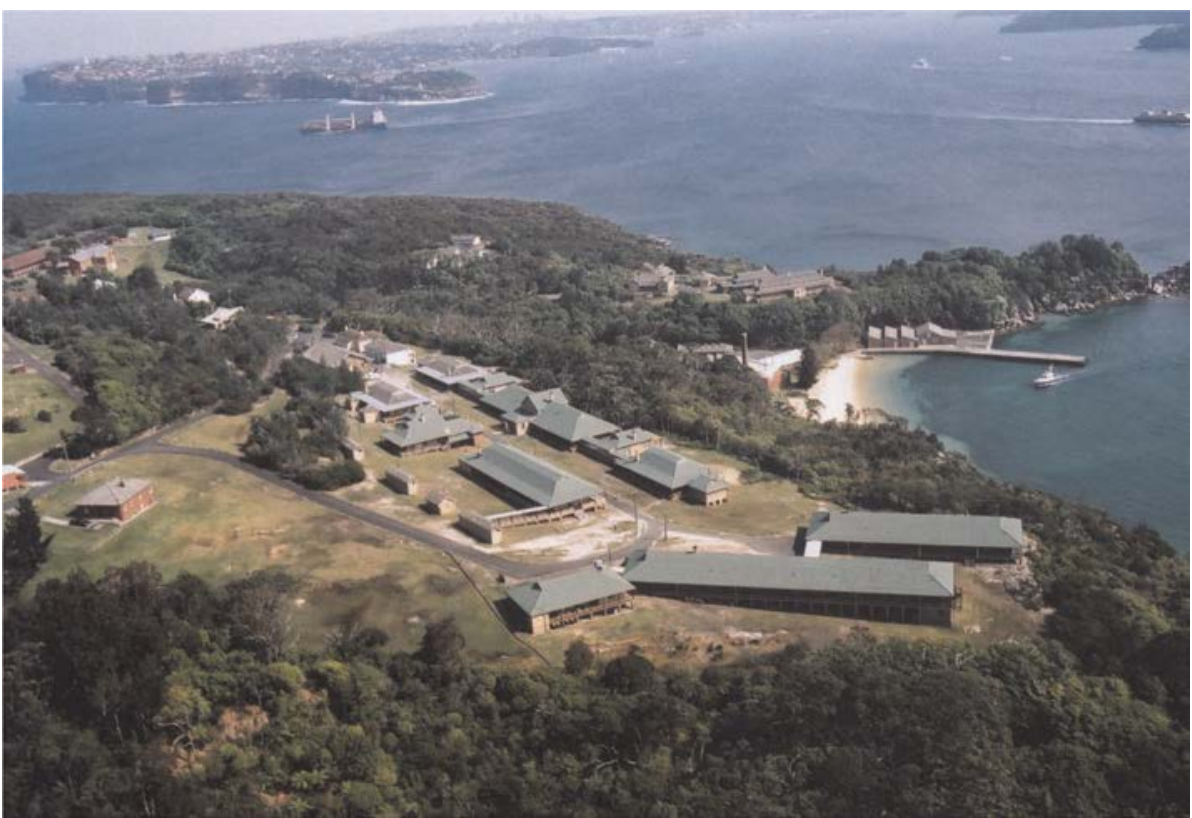

Figure 1. The site.

Source: Mawland Property Group 2007. 
to ensure its restoration and ongoing maintenance. Buckley (2004b) reviewed a series of options for the funding of national parks infrastructure. The paper thoroughly reviewed current funding processes and presented a series of recommendations as to the future of funding in these areas. However, the philosophical change of conceptualising national parks from a public good to a marketable commodity with economic value has caused much derision in sections of the community. As Buckley (2004b) suggests, the protected area agencies want to use tourism as a conservation tool, whereas the tourism interests want to use conservation as a tool for tourism development.

The site was put out for tender to provide a mechanism for ongoing maintenance and a commercial incentive to take on the redevelopment. After a long and bitter public debate about the redevelopment of the site and the tendering process, the project was 'won' by the Mawlands Group who had a successful history of involvement in tourism based cultural heritage redevelopments (Mawland Hotel Management, 2005). The rationales discussed by Buckley (2004b) are clearly articulated by the director of the successful tender of the Quarantine Station:

Mawland's proposed adaptive reuse of the site has been designed to generate sufficient wealth to better conserve the site and increase public access, interpretation and marketing. The Proposal will also return a profit share to the National Parks and Wildlife Service for the conservation of other cultural heritage sites within Sydney Harbour National Park. The Environmental Impact Assessment of the Proposal required Mawland's consultants to identify the condition of the site, past spending on conservation, public access and interpretation, and the economic impacts resulting from the Proposal. This exercise should provide some ideas and lessons to enhance the economic management of other heritage sites (McArthur, 2001, p. 130).

The Mawland proposal was the only one that did not propose a major new hotel on the site. For such a significant site there has been relatively little academic work published on tourism (Buckley, 2004a, 2004b; Wearing \& Darcy, 1999). Natural area conservation in NSW is largely orientated toward an ecocentric ethic with little attention placed on the built environment elements of the site, and the cultural heritage that it offers. For a contemporary use of facilities substantial maintenance of the built environment must occur. This is a noted cost of operation whether the cultural heritage site is open to the public for use or not. If the site is to be opened for public use then further ongoing operational maintenance must become part of the daily management practice. Further, there are other substantial costs that management face if they are to provide interpretation services to enhance the visitor experience as suggested in the Tourism White Paper.

The methodology

The method employed in this case study takes direction from Yin (2002) to provide insights into stakeholder perspectives. A qualitative research approach has been used, which employs the Quarantine Station as the object of study. It should be noted that the intent of this study is not to generate theory but to describe and interpret a specific situation and, in so doing, attempt to develop mechanisms that will enable future research to be better informed as to the public perceptions towards PPPs. These outcomes are both legitimate and worthwhile in the context of qualitative analysis. The information sources drawn upon for the study are newspaper articles where a detailed analysis of stakeholder perceptions is undertaken.

Collectively, the information gathered in the case study served as the data from which a 'chain of evidence' was compiled for analysis (Yin, 2002). The period set was 1990-2003, which was the chronological period in which the public debate took place over the PPP. The 
newspaper articles were drawn from the online databases of the local newspaper, Manly Daily, and the regional newspaper the Sydney Morning Herald. The online searching used a variety of terms to capture as broad a spectrum of articles identifying the North Head, Quarantine Station. After the preliminary search, some 450 articles were identified before each article was sourced and assessed for its merits to include in the sample. This was determined by the manner in which the article dealt with the Quarantine Station redevelopment. By far the majority of articles were excluded because they were related to recreational/tourism events and activities taking place at the site rather than the redevelopment of the site. One hundred and twenty newspaper articles were included in the sample $\left(n^{1 / 4120)}\right.$. Each article was analysed to determine stakeholder perspectives of the proposal. Within the body of the text, the stakeholder represented will be identified. For the sake of brevity of the article, the individual newspaper articles will not be referenced individually.

The analysis involved a 'qualitative content analysis' (Henderson, 1991; Hsieh \& Shannon, 2005; Krippendorff, 2004; Morgan, 1993) of local and regional newspaper articles addressing the redevelopment of the Quarantine Station. Content analysis is based on the nature of ideas, texts, media, talk and behaviour of social arenas that socially construct knowledge and power. In the tourism context, this could include a range of sources including interviews and focus group transcripts, personal communication, letters, brochures, directories, initiatives, policy documents and services offered at the site. However, this research restricted itself to the media representation of stakeholder perspectives and the discourses presented. It is recognised that the media is a significant player in shaping public attitudes towards development, while also being a stakeholder. In this case, however, the newspaper media was used as a data source rather than as a stakeholder in the case study. It is argued that newspaper articles are representative of the discourse of publicly presented ideological positions of the stakeholders. As shown in Figure 2, Turner's (1981) adapted continuum of anthropocentric versus ecocentric arguments for maintaining national parks was used to reflect the 'changes in park management, which are attributable to developments in environmental attitudes promoted by the national parks movement' (Turner, 1981, p. 156). This was chosen as the continuum because of its use in framing policy arguments within the NSW NPWS agency. As time progressed, the anthropocentric versus ecocentric argument became the generally accepted framework within environmental management (Eckersley, 1992).

To provide further differentiation of the stakeholders in the media it has also been recognised that the community often organise themselves against proposed development in their local area and this may be identified as a conservative reaction referred to as NIMBYism. NIMBY refers to the 'protectionist attitudes of and oppositional tactics adopted by community groups facing an unwelcome development in their neighbourhood' (Dear, 1992, p. 288), which tourism has been identified as engendering (Misener \& Mason, 2006; Mottiar \& Quinn, 2003; Nepal \& Chipeniuk, 2005). The prevailing attitude of NIMBY

\begin{tabular}{|c|c|c|c|c|}
\hline \multicolumn{3}{|l|}{ Ecocentrism } & \multicolumn{2}{|c|}{ Anthropocentrism } \\
\hline $\begin{array}{l}\text { Nature } \\
\text { Protection }\end{array}$ & $\begin{array}{l}\text { Nature } \\
\text { Protection } \\
\text { \& Outdoor } \\
\text { Recreation }\end{array}$ & $\begin{array}{l}\text { Recreation - } \\
\text { Protection }\end{array}$ & $\begin{array}{l}\text { Outdoor } \\
\text { Recreation } \\
\text { and Nature } \\
\text { Protection }\end{array}$ & $\begin{array}{l}\text { Outdoor } \\
\text { Protection }\end{array}$ \\
\hline
\end{tabular}

Figure 2. Adapted from Turner's (1981) continuum.

Source: Adapted from Turner (1981) to be inclusive of the anthropocentric versus ecocentric continuum (Eckersley, 1992). 
is a general agreement that the development, whether it is good or bad for the broader community, should not take place in the local area. Traditionally, NIMBY sentiments have been geared against the construction of human-use facilities such as nuclear power plants, heroin injection rooms, airports and in certain circumstances group homes, which are necessary in any developed nation but not desirable to those in the local neighbourhood (Hubbard, 1998; Wester-Herber, 2004). In creating a stakeholder map of the perspectives offered by the various stakeholders on the Quarantine Station, the NIMBY syndrome is used to bridge the difference between Turner's anthropocentric and ecocentric values and those stakeholder groups whose quotes in the newspapers reflected opposition to the development not necessarily for environmental reasons but as a catchall for a 'not-in-my-Manly’ attitude.

\section{Findings and discussion}

A plethora of individuals and groups could be regarded as stakeholders in the proposed redevelopment of the Quarantine Station. These ranged broadly from people with an interest in Australian history, local residents surrounding the Manly-North Head area, people who visit national parks, interested developers and others. When an inquiry into the Quarantine Station redevelopment was called, some 1347 written and 93 verbal submissions were made. However, in the media only a relatively small number of individuals and groups became actively involved in the contestation over the site. Of these, six major stakeholder group affiliations could be identified. Table 2 presents a stakeholder table that shows the relative groupings.

Local government political interests included not only those people elected to local council but also those that spoke on behalf of people from the local area including the

Table 2. Stakeholder groupings.

Stakeholders Individuals or groups associated with this aggregation

Local Government:

NPWS

Heritage Council

Developer

Friends and others

State Government

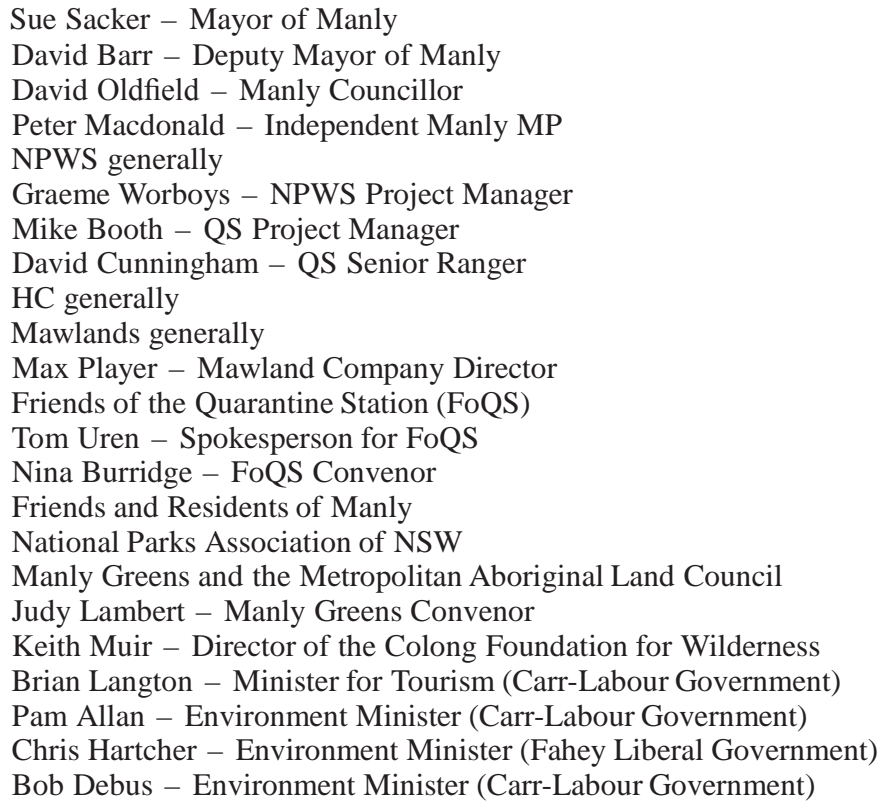


State local member. NPWS were largely restricted to spokespeople for the project as would be expected with a statutory authority. The Heritage Council became the voice of official cultural heritage representation. While the tendering process was open to all developers, there was an absence of involvement in the public debate until a preferred tender was announced. Once this had occurred, Mawlands Property Group was heavily represented in the media. By far the most diverse of the stakeholder groupings was the Friends and Others, who were dominated by the Friends of the Quarantine Station. This also included groups with a long history of involvement in local development issues. Lastly, the NSW State Government was represented by a variety of ministers and ministerial spokespeople.

A starting point for the analysis is the number of times a stakeholder group or individual has been referred to in the articles relating to the redevelopment of the Quarantine Station. Figure 3 represents the number of times that the stakeholder groups were referred to in articles and then provides the comparison based on which paper the reference occurred.

The graph clearly illustrates that the Sydney Morning Herald (SMH) referred to the NSW State Government by name more than any other stakeholder group and made least reference to the Heritage Council. The Manly Daily similarly has also made the least reference to the Heritage Council but has referred to the developer in more articles than any of the remaining stakeholder groups. In fact, the Manly Daily represented the developer's views at a rate $17 \%$ above that of the State Government and $40 \%$ above that of the local interest groups. This would appear surprising given the orientation of the local paper to local issues as compared with that of the Sydney Morning Herald, a newspaper delivered state-wide.

Conversely, the Sydney Morning Herald represented the views of State Government $43 \%$ above that of the local interest groups and 104\% above that of the developer. The relative prominence of the State Government in the media discourse is not surprising given that it was their policy change that was driving the debate and, hence, a great deal of the focus was placed on the Ministers in charge of the Department of Environment and Conservation driving the policy change to respond to criticisms. In this sense, the NPWS as a statutory authority of the government are simply implementing State Government policy. The

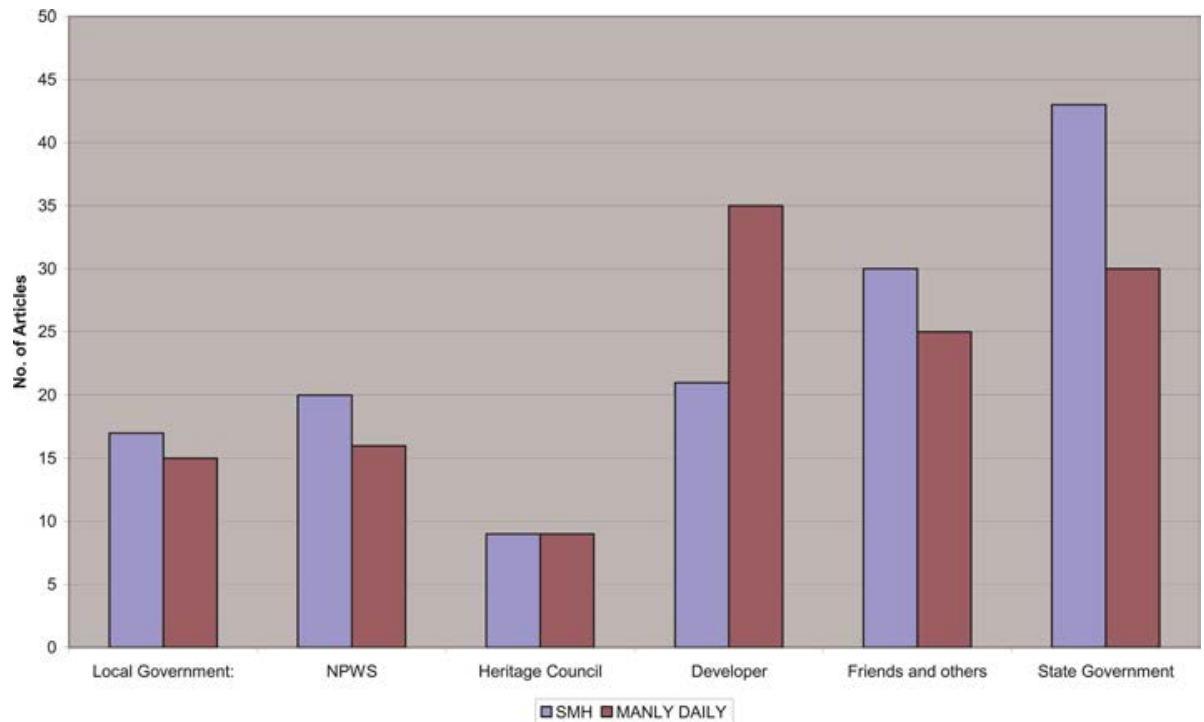

Figure 3. Overview of stakeholder newspaper articles - SMH and Manly Daily. 
other contributing State Government discussion came from the Minister of Tourism in support of the redevelopment as an important economic or underlying infrastructure facilitator.

Under the Australian Constitution, local government has no control of the decisionmaking process for this type of development. Therefore, it is relegated to the position of an observer of the process. As discussed earlier in this paper, the Manly local government has had a history of intense debate about development in the area. The council could be described as finely balanced between the pro-development and local interest/conservation lobbies. This has seen the nature of the council change at election time. The Quarantine Station redevelopment became another focus for a display of this rivalry. The nature of the local debate was not so much about the merits of the redevelopment but NIMBY like in the arguments presented. This grouping had by far the largest number of contributors to the debate. As such, Figure 4 presents a stakeholder map of the relative centrality of the stakeholders to the issue as represented in the media.

\section{Turner's ecocentric - anthropocentric spectrum}

While the quantitative representation of the newspaper articles provide an insight into the relative representation of the stakeholders at the regional and local level, more can be ascertained by analysing their ideological representation in the media. As a starting point, Table 3 presents a representative a quote from stakeholder groups' media comments to provide an understanding of their main perspective of development.

All media comments of the stakeholders were then content analysed based on a modified Turner's ecocentric/anthropocentric and NIMBY spectrum. Figure 5 presents a chart of the analysis to represent the ideological views of the stakeholder groups. The following discussion presents the discourse of the ideological representations.

The research shows that while the State Government, Mawlands and NPWS had the highest media representation there were comparatively few direct quotes from these

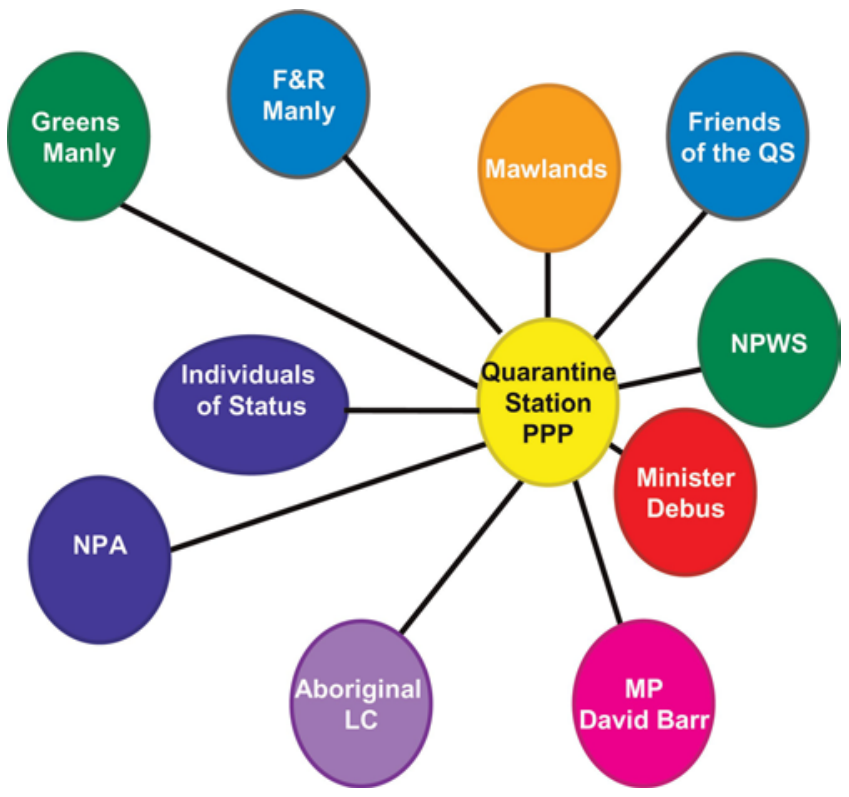

Figure 4. Stakeholder map. 
Table 3. Stakeholder quotes.

\begin{tabular}{|c|c|}
\hline Stakeholder & Representative quote \\
\hline \multicolumn{2}{|l|}{ Local Government } \\
\hline Sue Sacker - Mayor of Manly & $\begin{array}{l}\text { Councillor Sue Sacker, said the plan was outdated and } \\
\text { inadequate to protect 'this precious and fragile site'. The } \\
\text { National Parks and Wildlife Service should prepare a new } \\
\text { plan from scratch 'rather than trying to shape the plan to its } \\
\text { current mindset that the site should be leased to a } \\
\text { developer' }\end{array}$ \\
\hline $\begin{array}{l}\text { David Barr - Deputy Mayor of } \\
\text { Manly }\end{array}$ & $\begin{array}{l}\text { 'The figures confirm that the Quarantine Station could easily } \\
\text { generate a profit under public ownership and management. } \\
\text { There is simply no financial imperative to lease it out' }\end{array}$ \\
\hline David Oldfield - Many Councillor & $\begin{array}{l}\text { 'But apart from that everything else on the site will just be } \\
\text { drastically improved' }\end{array}$ \\
\hline Peter Macdonald - Independent & 'You are, in effect, privatising the Quarantine Station’ \\
\hline
\end{tabular}
Manly MP

\author{
State Government
} NPWS Graeme Worboys - NPWS Project
Manager

Mike Booth - QS Project Manager

David Cunningham - QS Senior Ranger

Heritage Council

Developer

Mawland Group

Max Player - Mawland Company Director

Friends and others

Tom Uren, Ex Federal Government Minister

Nina Burridge - FoQS Convenor
‘. . the Quarantine Station requires 'a substantial injection of funds, with an on-going annual commitment. ..'NPWS are attempting to balance the needs and demands of recreation with preservationist values'..... the NPWS is in the middle of the privatisation and parks dilemma'

'.. the idea was to steer tourists towards 15 key regional parks, with five in the Sydney area. An international tourist promotion will be launched to attract visitors to these 15 destinations'

'There's a detailed conservation plan that took three years to do and that's the bible as far as we're concerned'

'And exposure to the elements up here has caused big problems. Sandstone buildings weather in the salty atmosphere at a phenomenal rate'

Its resolution said the partnership 'is a positive initiative towards the consideration of financial issues and the longterm conservation of the site'

'Mawland would spend a budget of \$14 million on conservation, restoration and maintenance of the site'. '... it is imperative that Mawland address the issues raised by these groups and work towards a partnership with them'... .'Mawland proposes to increase opportunities for public use of the area by offering waterfront dining, accommodation and more tours'

‘... apart from a 'philosophical problem' of public land going to a private enterprise, the community had nothing to worry about'

'.. our historic places define our identity, providing a sense of how the past has shaped us'

'We are saying to the State Government that there are different management options available which are in keeping with sustainable (and compatible) development of a site which is part of our national heritage' 
Table 3. Continued.

\begin{tabular}{|c|c|}
\hline Stakeholder & Representative quote \\
\hline National Parks Association of NSW & $\begin{array}{l}\text { ' } \ldots \text { puts commercial development above the chance [of] a } \\
\text { long-term co-operative plan to conserve the unique } \\
\text { cultural and natural heritage on Sydney’s doorstep' }\end{array}$ \\
\hline $\begin{array}{l}\text { Judy Lambert - Manly Greens } \\
\text { Convenor }\end{array}$ & $\begin{array}{l}\text { 'The last thing we want to do is ruin our parks with economic } \\
\text { rationalism' }\end{array}$ \\
\hline $\begin{array}{l}\text { Keith Muir - Director of the Colong } \\
\text { Foundation for Wilderness }\end{array}$ & ‘It sounds like parkland real estate - nature for sale’ \\
\hline State government ministers & \\
\hline $\begin{array}{l}\text { Mr Hartcher Minister for the } \\
\text { Environment }\end{array}$ & $\begin{array}{l}\text { There would be 'no crass development under this } \\
\text { Government but an enhancement of the existing facilities } \\
\text { to encourage greater appreciation of our heritage' ... 'The } \\
\text { plans have the potential to attract } 10 \text { times the current } \\
\text { number of visitors', he said }\end{array}$ \\
\hline $\begin{array}{l}\text { Mr Debus - Minister for the } \\
\text { Environment }\end{array}$ & $\begin{array}{l}\text { 'all buildings, flora and fauna will be fully protected' and that } \\
\text { the scheme will 'ensure greater public access [to the site] in } \\
\text { a way that generates sufficient funds to ensure its long- } \\
\text { term conservation'. }\end{array}$ \\
\hline
\end{tabular}

Sources: Sydney Morning Herald and Manly Daily (references removed due to article length considerations).

organisations. NPWS were charted as being representative of both ecocentric and anthropocentric perspectives as evidenced by the direct quotations in Table 3. These quotes were a reflection of their management objectives, which are to conserve the environment while managing the resource for economic and social activities. Prior to the tender, the NPWS were both the leaser and protector of the site, yet they were unable to properly maintain

NPA

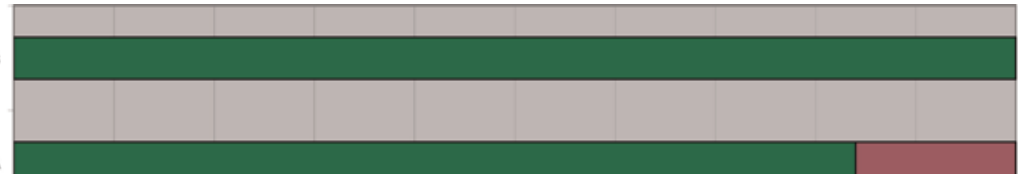

Friends/Res Manly

FoQS

S

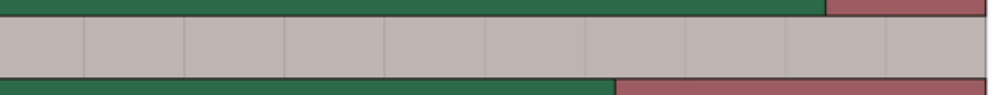

State Government
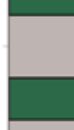

NPWS
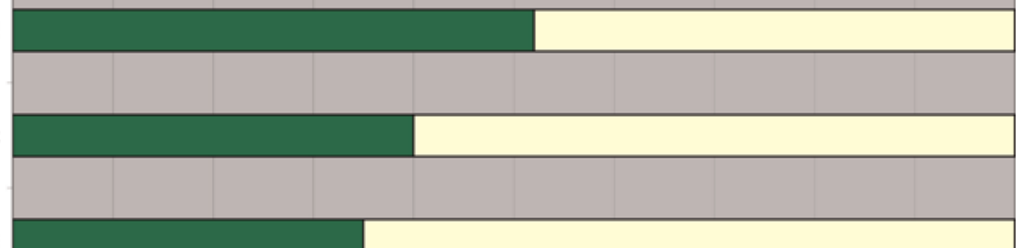

Mawlands

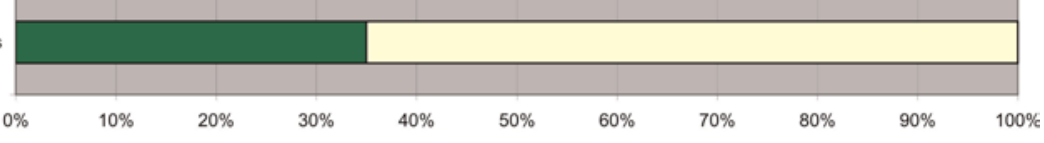

口Ecocentric $\square$ Nimby $\square$ Anthropocentric

Figure 5. Stakeholder's ideological media representation. 
it. The NPWS are in the middle of the privatisation of parks dilemma, where they are the organisation responsible for implementing State Government policy. The role of the regulator and revenue generator is an uncomfortable one for government statutory authorities. On the one hand, they are to protect and conserve the resource and, on the other hand, promote new and innovative uses that may compromise the agency's primary objective.

It is not surprising that Mawland, as tender from the private sector with a profit incentive, demonstrated both ecocentric and anthropocentric values. Mawland have a demonstrated record of accomplishment in cultural heritage tourism businesses where they have demonstrated sensitivity to the restoration of buildings. The development itself is subject to all the considerations of the NSW Environmental Planning and Assessment Act, 1979, which includes significant ecological and cultural environmental impact assessment (Manidis Roberts Consultants, 2004). They are acutely aware of the controversial nature of the development, need for best practice environmental management and a need to mitigate any impact of the development on the site. Further, they were at pains to be seen to ensuring public access to the site. Within this regulatory environment, they had committed to a substantial financial outlay to upgrade the infrastructure of the site, which will require a substantial cash investment to derive a profit in the medium to long term.

The Friends of the Quarantine Station (FoQS) were frequently quoted directly in both the regional and local newspaper. A main spokesperson for the FoQS was Tom Uren, a former senior minister in a Federal Labour governments and a well-known Sydney activist for the protection and preservation of the Sydney Harbour. Additionally, the group invited national environmental spokesperson Peter Garrett to speak at their AGM in 2001. This is particularly noteworthy, as Turner (1981, p. 157) points out that pressure groups are at their most powerful when they have been able to 'call on the support of influential politicians and bureaucrats, as well as popular grass roots support'. The following quotes are representative of the ideological position of the FoQS:

'It is the integrity of the site that we are trying to preserve. Once you hand over such a site to a commercial developer for such a long period, we, the community, will lose control of it and the site will lose its significance. It will become just another theme park along the Sydney foreshore'.

'Private control of any national park cannot be justified on any grounds'.

The above examples indicate two reoccurring arguments of the FoQS. First, that the government has a civic duty to preserve the heritage of the site. Second, that private intervention would result in a loss of control over the Quarantine Station and its future. Their ecocentricism is not based so much on a pure environmentalist philosophy of allowing 620 the natural heritage to exist for its own sake, but rather the group are seeking to protect it from the exploitation they believe it would experience under private involvement.

The stakeholder group that was considered to harbour a NIMBY philosophy was the Friends and Residents of Manly Group who suggested alternatives to the proposed Mawland development. Essentially, this group did not express a strong sentiment to oppose the development on environmental or cultural grounds but instead called for alternatives that seek to combine both the private and public sectors with the involvement of other 'interested bodies'. For example:

'We suggest these (alternatives) include a broad range of options including government financial support, mothballing until financial support is available, incremental increase in usage under NPWS control, trusts, coalitions of interested bodies, to name a few'. 
These sentiments were further developed by a series of local political identities like Independent Manly State MP David Barr, whose media representation is limited to the local newspaper. For example, he claimed that:

'The NPWS is clearly losing sight of its primary responsibilities in favour of commercial opportunism and this is quite unacceptable'.

'We will try to stop it because it will be signed and then it (the deals) is locked in before the community knows the details’.

These quotes indicate the strong anti-privatisation sentiment together with maintaining the status quo - public sector control of the site. The other component of the underlying discourse was that increased visitation to the site would also increase congestion issues in Manly. Therefore, the status quo was preferable to any change in management option. Alternatively, the Manly Greens (a local political party) revealed a considerably more preservationist attitude and are therefore positioned at the ecocentric end of the spectrum:

'The private lease development as proposed is not appropriate for a national heritage site, nor would it comply with requirements outlined in the draft conservation plan’.

The various government ministers' perspectives were encapsulated by the State Environment Minister Bob Debus who expressed both ecocentric and anthropocentric views regarding the proposed development:

'The idea that the quarantine station can be maintained without some form of adaptive reuse is at many levels impractical'.

'Leasing of historic buildings has proved to be an effective vehicle for conservation, if it is done properly’.

The Minister also stated that 'there are two approaches to conserving heritage buildings; they can be put in mothballs and all visitors turned away for fear they might damage the buildings or they can be sensitively conserved, adapted and reused to bring their history alive for the enjoyment of visitors both today and in the future'. This quote captures the philosophy of the Ministers' who realise the multiplicity of issues facing the management of the Quarantine Station. These issues involve the maintenance cost of infrastructure for public use, as well as the constraints placed on the site due to the current budgetary arrangements.

\section{Other considerations}

This type of contestation has been noted through the urban political economy and environmental planning literature. Sandercock and Berry's (1983) seminal work suggests that the free flow of information is a precondition for successful participation in planning. Without a free flow of information, misleading and ill-informed views of some stakeholders can be passed on to the community. Lack of communication between government and the public can be a precursor to public action. In particular, the feeling that decisions are been made without community consultation or an indifference to the consultation can lead to a surge of public involvement. Of course, as they note, public involvement heightens in the latter stages of development decision-making. This is not a new phenomenon but one that has increased over the time of PPPs where the public believe they have not been 
adequately informed nor had free access to all of the information in the development process. There was certainly a belief in the minds of some stakeholders that this was the case with the Quarantine Station and this became an area of contention. Yet, the NSW Environmental Planning and Assessment Act 1979 [NSW] incorporates provisions for third-party appeal of development decisions based on procedures of the Act not being followed. None of the local stakeholders has sought to use of this section of the Act to challenge the development procedures undertaken by the NPWS (Stein \& Farrier, 2006).

Public participation in planning is inherently flawed because it can fail to address the needs of those members of the community who are not involved in a pressure group and who may be less educated, articulate or may not be politically connected, yet are also affected by the development. According to Turner (1981, p. 158), 'there is consistent support for the hypothesis that pressure group leaders are unrepresentative of the general public and even the grass roots membership of their own groups'. However, an examination of the social profile of Manly demonstrates that compared with other areas of Sydney, Manly is characterised by consistently low unemployment, high percentage of home owners, and professional high income earners (Australian Bureau of Statistics, 2002). Outside of those actively involved in stakeholder groups, the Quarantine Station redevelopment may have been an inconsequential issue for most members of public. Given this situation, it is recognised that a considerable limitation to this present research was the inability to gauge the reactions of those residents not actively involved in the stakeholder groups. Six stakeholder groupings condemned the proposal, for various reasons, few suggested alternatives and only three out of nine praised the proposal. Sandercock and Berry (1983, p. 83) point out that wanting to prevent certain changes is not necessarily bad - but it can often 'create as many problems as it solves if simple prevention is the aim rather than offering constructive alternatives'.

The debate over the proposal to redevelop, or adaptively reuse the Quarantine Station has taken place over a decade and was only recently resolved. This in itself provides an understanding of the value and the passion that stakeholders place on the site. The Quarantine Station was such a contested site as the stakeholder groups associated it with rich cultural history and heritage, for example, 'our historic places define our identity, providing a sense of how the past has shaped us'. There also exists a concern that the lease of the site to a private developer would put this 'national heritage' site in jeopardy. This was not only a result of the Quarantine Station being essentially a public good but also due to its high historical and cultural heritage value. The research identified emotive responses from the stakeholders regarding the value they attach to the site, most of which were found in the local newspaper.

Anthropocentric views of national parks or areas of cultural heritage suggest that 710 leaving them in a preserved state and not allowing use may risk a loss of value. This is because historic buildings such as those found on the Quarantine Station site have no public meaning if kept in a preserved state. It is only through human valuing and interpretation that these sites become significant (Hall \& Tucker, 2004). Interpretation of historic buildings and townscapes often attracts high levels of debate because the site may not be interpreted to reflect a true representation of history (Hall \& Tucker, 2004). Inappropriate representation through marketing heritage specifically for tourism was a concern of FoQS where they felt, 'it will become just another theme park along the Sydney foreshore'.

The proposal to adaptively reuse the Quarantine Station was selected following stringent guidelines set out by the NPWS. The decision was dependent on the outcome of an environmental impact study and a species impact study. An independent commission of inquiry was also undertaken, separate from both the government and Mawland 
(Mawland Hotel Management, 2005), which found that private sector lease involvement would be both economically and environmentally sustainable (NSW National Parks and Wildlife Service, 2004). In spite of this, the private developer has not been able to secure crucial community support for the project as played out in the local and regional newspapers.

\section{Conclusion}

PPPs in the area of cultural heritage tourism are still being debated as a means of managing national parks in neo-liberalist societies. Research over the next few years will determine the foundations for what will be developed in this area. Yet, PPP's have not led to any wholly privatised national parks in Australia. It is suggested that the outcome of the 16year debate over the Quarantine Station in Sydney is an example of cultural heritage tourism, which could have a large impact on the future of private involvement in national parks and parks management.

The case study has provided insights into this process using stakeholder perspectives. The observations provided emphasise the high regard that the Australian public holds for its cultural heritage and its desire to ensure that any attempts to privatise these assets are thoroughly scrutinised. The case study presented here provides the basis to examine the changing role of national parks management at the Quarantine Station. The research approach used represents only one mechanism to examine the phenomenon. The authors suggest that through understanding the stakeholder's perspectives future PPPs can be managed more effectively. As with all public goods, use of national parks are becoming more contested in neo-liberal societies where decreasing government involvement is compounded with increased use and changing expectations for these important public assets. If ways forward are to be created, better mechanisms for understanding stakeholder perspectives need to be incorporated by the organisations involved in bringing new forms of management to the national estate.

Author Biography

\section{References}

Australian Bureau of Statistics (2002). Sydney: A social atlas, Retrieved from http://www.abs.gov. au/ausstats/abs\%40.nsf/7884593a92027766ca2568b5007b8617/cc3d989b1dab6208ca256889 00222129 !OpenDocument.

Bella, L. (1987). Parks for profit. Montreal: Harvest House.

Borrini-Feyerabend, G. (1996). Collaborative management of protected areas: Tailoring the approach to the context. Switzerland: IUCN, The World Conservation Union.

Buckley, R. (2004a). A natural partnership: Making national parks a tourism priority: Project paper 2: Innovative funding mechanisms for visitor infrastructure. Sydney: Transport and Tourism Forum.

Buckley, R. (2004b). Partnerships in ecotourism: Australian political frameworks. The International Journal of Tourism Research, 6(2), 75.

Buckley, R., Pickering, C., \& Weaver, D.B. (2003). Nature-based tourism, environment and land management. London: CABI.

Burns, P.M. (2004). Tourism planning: A third way? Annals of Tourism Research, 31(1), 24-43.

Charters, T. (1996). Ecotourism: A tool for conservation. In T. Charters, M. Gabriel, \& S. Prasser (Eds.), National parks: Private sector's role (pp. 77-92). Toowoomba: USQ Press. 
Christoff, P. (1998). Degreening government in the garden state: Environment policy under the Kennett Government, 1992-1997. Environment Planning and Law Journal, 15(1), 10-32.

Commonwealth Department of Industry Tourism and Resources (2003). Tourism white paper - The medium to long-term strategy for tourism. Canberra: Author.

Commonwealth Grants Commission (2006). Visitor numbers (National Parks and Wildlife Services), Retrieved from http://www.cgc.gov.au/

Cree, D. (1985). Is there a role for concessionaires in national parks?, Unpublished manuscript, University of Technology Sydney, Sydney.

Darcy, S., Griffin, T., Craig, M., Crilley, G., \& Moore, S. (2007, 11-14 February). Protected area visitor data collection and management: Emerging issues and gaps in current Australian practices., Paper presented at the 17th annual conference of CAUTHE tourism: Past achievements, future challenges, Manly, Sydney, Australia.

Davis, G., Wanna, J., Warhurst, J., \& Weller, P. (1993). Public policy in Australia. Sydney: Allen \& Unwin.

Dear, M. (1992). Understanding and overcoming the NIMBY syndrome. Journal of the American Planning Association, 58(3), 288-300.

Dredge, D., \& Jenkins, J. (2003). Federal-state relations and tourism public policy, New South Wales, Australia. Current Issues in Tourism, 6(5), 415-443.

Eagles, P.F.J., McCool, S.F., \& Haynes, C.D. (2002). Sustainable tourism in protected areas. Switzerland: IUCN, The World Conservation Union.

Easterling, D.S. (2004). The residents' perspective in tourism research: A review and synthesis. Journal of Travel \& Tourism Marketing, 17(4), 45-62.

Eckersley, R. (1992). Environmentalism and political theory: Toward an ecocentric approach. London: Routledge.

Figgis, P. (1999). Australia's national parks and protected areas: Future directions, a discussion paper. Sydney: Australian Committee for IUCN.

Freeman, R.E. (1983). Strategic management: A stakeholder approach. Advances in Strategic Management, 1, 31-60.

Gabriel, M. (1996). Private sector’s role in national parks: An overview. In T. Charters, M. Gabriel, \& S. Prasser (Eds.), National parks: Private sector's role (pp. 1-11). Toowoomba: USQ Press.

Hall, C.M. (1999). Rethinking collaboration and partnership: A public policy perspective. Journal of Sustainable Tourism, 7(3), 274-289.

Hall, C.M., \& Tucker, H. (Eds.). (2004). Tourism and postcolonialism: Contested discourses, identities and representations. London, New York: Routledge.

Henderson, K.A. (1991). Dimensions of choice: A qualitative approach to recreation, parks, and leisure research. State College, PA: Venture Publishing.

Herath, A., \& Kennedy, J. (2004). Estimating the economic value of Mount Buffalo National Park with the travel cost and contingent valuation methods. Tourism Economics, 10(1), 63.

Hsieh, H.F., \& Shannon, S.E. (2005). Three approaches to qualitative content analysis. Qualitative Health Research, 15(9), 1277.

Hubbard, P. (1998). Community action and the displacement of street prostitution: Evidence from British cities. Geoforum Social Exclusion, 29(3), 269-286.

Inglis, J., Whitelaw, P., \& Pearlman, M. (2006). Best practice in strategic park management: Towards an integrated park management model. Brisbane: Sustainable Tourism Cooperative Research

800 Centre. Jamal, T.B., \& Getz, D. (1995). Collaboration theory and community tourism planning. Annals of Tourism Research, 22(1), 186-204.

King, S., \& Pitchford, R. (1998). Privatisation in Australia: Understanding the incentives in public and private firms. The Australian Economic Review, 31(4), 313-328.

Krippendorff, D.K. (2004). Content analysis: An introduction to its methodology. Beverly Hills, CA: Sage Publications.

Lockwood, M., \& Dirk, D.H. (2001). Value conflicts between natural and cultural heritage conservation - Australian experience and the contribution of economics., Paper presented at the heritage economics: Challenges for heritage conservation and sustainable development in the 21st century, Canberra: Australian National University.

Manidis Roberts Consultants (2004). Quarantine Station - environmental impact statement, Retrieved from http://www.nationalparks.nsw.gov.au/npws.nsf/Content/QuarantinebStationbpenvironmentalpimpactpstatement. 
Mawland Hotel Management (2005). Quarantine Station, Retrieved from http://www.q-station.com. $\mathrm{au} / \mathrm{reasons} . \mathrm{html}$

McArthur, S. (2001). The economic rationale for adaptive reuse - case study of the North Head Quarantine Station., Paper presented at the heritage economics: Challenges for heritage conservation and sustainable development in the 21st century, Canberra: Australian National University.

Misener, L., \& Mason, D. (2006). Creating community networks: Can sporting events offer meaningful sources of social capital? Managing Leisure, 11(1), 39-56.

Mitchell, R.K., Agle, B.R., \& Wood, D.J. (1997). Toward a theory of stakeholder identification and salience: Defining the principle of who and what really counts. The Academy of Management Review, 22(4), 853-886.

Morgan, D.L. (1993). Qualitative content analysis: A guide to paths not taken. Qualitative Health Research, 3(1), 112.

Mottiar, Z., \& Quinn, B. (2003). Shaping leisure/tourism places - the role of holiday home owners: A case study of Courtown, Co. Wexford, Ireland. Leisure Studies, 22(2), 109-127.

Nepal, S., \& Chipeniuk, R. (2005). Mountain tourism: Toward a conceptual framework. Tourism Geographies, 7(3), 313-333.

NSW National Parks and Wildlife Service (2001). Quarantine Station - detailed area conservation management plan, Retrieved from http://www.nationalparks.nsw.gov.au/npws.nsf/Content/ Quarantine PStation pdetailedpAreapconservationpmanagementpplanp2001

NSW National Parks and Wildlife Service (2004). Quarantine Station, Retrieved from http:// www.nationalparks.nsw.gov.au/npws.nsf/content/northpheadpquarantinepstation

Page, S. (2006). The geography of tourism and recreation: Environment, place, and space. London: Routledge.

Peter Freeman Pty Ltd (2000). North Head Quarantine Station conservation management plan, Retrieved from http://www.nationalparks.nsw.gov.au/npws.nsf/content/quarantinepstationp conservationpmanagementpplanp2000

Prasser, S. (1996). Forward. T. Charters, M. Gabriel, \& S. Prasser (Eds.), National parks: Private sector's role. Toowoomba: USQ Press.

Ready, R., \& Navrud, S. (2002). Valuing cultural heritage: Applying environmental valuation techniques to historic buildings, monuments and artifacts. Cheltenham: Edward Elgar Publishing Ltd.

Sandercock, L., \& Berry, M. (1983). Urban political economy: The Australian case. Sydney: George Allen \& Unwin.

Sautter, E.T., \& Leisen, B. (1999). Managing stakeholders a tourism planning model. Annals of Tourism Research, 26(2), 312-328.

Sibly, H. (1998). The pricing and management of walking tracks in Tasmania. The Australian Economic Review, 31(4), 345.

Stein, P.L., \& Farrier, D. (2006). The environmental law handbook: Planning and land use in NSW (4th ed.). Sydney: UNSW Press.

840 Timothy, D.J., \& Boyd, S.W. (2006). Heritage tourism in the 21st century: Valued traditions and new perspectives. Journal of Heritage Tourism, 1(1), 1-17.

Turner, A. (1981). National parks and pressure groups in New South Wales. D. Mercer (Ed.), Outdoor recreation: Australian perspective (pp. 156-174). Malvern: Sorrett Publishing.

United Nations Environment Programme (2005). Forging links between protected areas and the tourism sector. Paris: Author.

845 Veal, A.J. (2002). Leisure and tourism: policy and planning. London: CABI.

Wearing, S., \& Darcy, S. (1999). Ecotourism options in coastal protected area management: A case study of North Head Quarantine Station. The Environmentalist, 18(4), 239-250.

Webb, R., \& Pulle, B. (2002). Research paper no. $12002-03$ - Public private partnerships: An introduction, Retrieved from http://www.aph.gov.au/library/pubs/rp/2002-03/03RP01.htm

Wester-Herber, M. (2004). Underlying concerns in land-use conflicts - the role of place-identity in risk perception. Environmental Science \& Policy, 7(2), 109-116.

Yin, R.K. (2002). Case study research, design and methods (3rd ed.). Thousand Oaks, CA: Sage Publications. 